\title{
Human Spirituality: Jean-Louis Chrétien and the Vital Side of Speech
}

\author{
Francesca Peruzzotti
}

check for

updates

Citation: Peruzzotti, Francesca. 2021 Human Spirituality: Jean-Louis Chrétien and the Vital Side of Speech. Religions 12: 511. https://doi.org/ 10.3390/rel12070511

Academic Editor: Neal DeRoo

Received: 27 May 2021

Accepted: 3 July 2021

Published: 8 July 2021

Publisher's Note: MDPI stays neutral with regard to jurisdictional claims in published maps and institutional affiliations.

Copyright: (C) 2021 by the author. Licensee MDPI, Basel, Switzerland. This article is an open access article distributed under the terms and conditions of the Creative Commons Attribution (CC BY) license (https:// creativecommons.org/licenses/by/ $4.0 /)$
Collegio dei docenti di Teologia, Università Cattolica del Sacro Cuore-Milano, 20123 Milan, Italy; francescaelide.peruzzotti@unicatt.it

\begin{abstract}
Jean-Louis Chrétien founded his phenomenological enquiry on an analysis of the word as defined by the call and response link. His analysis provides an in-depth approach to spiritual experience as a basis for authentic religious experience. The description of the theoretical sites in which he confronts the theme of the spirit (vital breath, Holy Spirit, inspiration of Scripture, and spiritual life and prayer) determines some fixed points that allow us to define spiritual experience as intersubjective and fleshly, and therefore, not reducible to solipsism and intimism.
\end{abstract}

Keywords: Bible; Jean-Louis Chrétien; community; intersubjectivity; prayer; spirit

\section{Introduction}

When we consider the human experience of one's relationship with God, we very frequently separate the sphere of religion from that of spirituality, where the former means the public and formal expression of the latter. ${ }^{1}$ Such an understanding of religion can be seen as a reduction of spiritual life because only the spiritual dimension is considered to express the personal free identity of the subject binding themself to God. Religion, with its communal and material aspects, is constantly at risk of becoming too concrete and unable to preserve the otherness of transcendence. ${ }^{2}$

However, this scheme, which operates by identifying radical oppositions (materialimmaterial, public-private, and communitarian-personal), is inadequate for describing the event of human exposure to transcendence. A dialogue with the phenomenological work of Jean-Louis Chrétien shows that spiritual experience, as such, is the foundation of the authentic religious dimension. The analysis of the theoretical places in which Chrétien confronts the theme of the spirit (vital breath, Holy Spirit, inspiration of Scripture, and spiritual life and prayer) leads to the delineation of the phenomenological device of call/response that characterizes his work. This, in turn, allows us to define spiritual experience as truly intersubjective and fleshly, and therefore, irreducible to solipsism and intimism. Chrétien's proposal can be useful to explain the spiritual dimension of religion not only because, in using the phenomenological approach, he overcomes every dichotomic reduction in favor of a persuasive unified approach to human subjectivity, but also because he directly deals with the concrete religious dimension, in particular its Christian form.

\section{Spirit as Vital Breath: Personal Communication}

Chrétien's philosophical style is very particular: his analyses are obtained through a rich and detailed comparison of many authors, who belong not only to the history of philosophical thought but also to the religious and literary heritage of humanity. Chrétien uses numerous citations from other works to build a polyphonic exhibition, which results in a global intertwining of voices, and from this intertwining an original and profound proposal unfolds. ${ }^{3}$ This polyphony also happens when Chrétien defines the human person as such: Chrétien uses quotations from many authors (from Rainer Maria Rilke to John of the Cross, from Francis Ponge to Gregory of Nazianzus) to highlight that the breath of 
life is one of the most powerful images for defining the fundamental aspects of humanity. The act of breathing - an action as essential as it is unconscious-can be analyzed to define subjectivity as originally relational. Just as Chretien's voice is never singular, but is the result of a plurality of voices, so too personal breath is possible only thanks to a large number of others' breaths. This leads to the conclusion that the spiritual dimension of existence is one of its constitutive features because the breath immediately corresponds to the spirit.

To show this, Chrétien begins with the relation between breath and the vital dimension of the wind, a dynamic and continuous movement that is therefore subject to constant modification. The fact that human beings live by breathing highlights the impossibility of defining the human as if it were a complete singularity, as if a solitary existence were possible.

Chrétien's philosophy is part of the phenomenological operation that denies the metaphysical presumption whereby the subject defines itself as a constituting ego, in itself absolute. The inquiries concerning breath contribute to this denial. In fact, the breath of life is recognized as the effective manifestation of the overcoming of interiority: breathing corresponds to a continuous communication between the inside and the outside, a constitutive relationship between what is welcomed and what is returned. The rhythm of life has this structure, from which and within which everyone can find their own identity.

Chrétien therefore affirms that "breathing is the perpetual and active rejection of solipsism" (Chrétien 2009a, p. 12). The human spirit, from its origin, is intersubjective. In fact, whoever breathes-every human being - must recognize that they have not gained that possibility through their own work but received it from elsewhere, first from those who created them and freely offered them the possibility of taking their first breath.

The act of breathing is thereby understood as the equivalent of the spiritual dimension that defines humans: designating spirit as breath is not just an image used to describe an immaterial dimension, but it has a deeper connection, which shows how universal and concrete spiritual constitution is. Consequently, the spiritual dimension cannot be understood as if it were linked only to interiority because the very breath-the foundation of the spirit- ${ }^{4}$ is the continuous emergence towards the exterior; every breath is delivered to the world. Nobody can breathe only for themselves: because the act of breathing implies a change in the general world's balance, the spiritual changes of every subject are not exclusively related to themself but have an originary consequence to the relationships the subject has with the others.

The spirit is received by others and is handed over to others, establishing a communal bond. Chrétien specifies that spirit is a communicative structure, even a communal one (see Chrétien 2009a, p. 24); referring to two biblical verses (Genesis 2:7 and John 20:22), he shows that "to transmit the breath is to transmit the power to transmit, to communicate the breath is to communicate the power to communicate" (see Chrétien 2009a, p. 14). According to Chrétien's reading of the Bible, what happens with the relationship between God and the creature, and what happens when Jesus gives the Holy Spirit to the disciples, are what happens in any truly intersubjective relationship. Life is more than communication between subjects because each one gives the other the possibility to communicate in turn. A bond of communion is therefore established between all subjects, so that transmitting the vital breath is a never-ending operation that does not cease in its effects. In fact, it is impossible to determine a hierarchy of spiritual contents, because what remains relevant is not what is transmitted but how it is transmitted as such: the structural link between humans.

This is possible because the breath corresponds to a fully free dynamic that is not predeterminable and whose form of expression cannot be decided. It is a question of welcoming the breath's manifestation even before defining it, so that its reception always involves an excess compared to what previously existed: "the breath, like the spirit, increases by its exchange" (Chrétien 2009a, p. 25). Chrétien's phenomenology does not emphasize the role of the first person as a constitutive one (according to an idealistic scheme that he attributes to Husserlian phenomenology and to modern philosophy), because such a role would still be a pre-determination of the possibilities of its power. On the contrary, the 
subject is called by life itself to discover its role and its value in the act of self-determination. This is not a reduction but allows a non-predeterminable measure of its life as such. For this reason, the responsibility of each subject is extreme: taking care of the spirit means taking care of its transmission, being aware of its fragility, and making every effort not to hinder it. Establishing a bond with the other is equivalent to responding to the responsibility received through life and, therefore, giving life in turn: "approaching someone is always, however discreetly, approaching with our breath, blowing in" (Chrétien 2009a, p. 27).

While describing the breath of life and constructing a parallel with the human spirit, Chrétien does not limit his analyses to establishing some universal characteristics. Rather, he inserts his reflection explicitly into the Christian tradition, referring to the form of spiritual life that it has proposed. Specifically, he points out that the link between the spirit and the concrete and carnal dimension is fulfilled by Christianity. The reduction of the spiritual dimension to interiority that has already been rejected at the anthropological level is now established with even more force: "all that is spiritual is also fleshly in the religion of the Incarnation" (Chrétien 2009a, p. 26). It is now essential to more specifically understand how Chrétien carries out his own philosophical investigation by considering what Christianity proposes.

\section{Fiery Call and Response: The Spiritual Act of Reading}

In the text dedicated to the breath as a fundamental human characteristic, Chrétien refers to the particular declaration of the spirit that Christian dogma recognizes as one of the three persons of the Trinity, the Holy Spirit. Chrétien addresses the sentence spoken by Jesus during his dialogue with Nicodemus ("The wind blows wherever he wishes"; John 3:8) and offers a particularly significant translation, which effectively links the Spirit to the breath: "the Spirit breath" (Chrétien 2009a, p. 15). The use of an anthropological image in order to describe one of the peculiar actions of God draws a deeper link between the human and the divine dimension; the Spirit is in fact distinguished by its connecting role (it is the love linking the Father and the Son, but also the bond offered to humanity by God through the gift realized by Jesus on the cross; according to Matthew 27:50, Jesus "yielded up his spirit"). It is interesting to consider how the human being, in its finitude, can welcome that Spirit and share not only the vital dimension of the human breath but also of the divine Breath. Chrétien addresses this question by focusing his analysis on a specific action that characterizes Christian life: the act of reading the Bible. Spiritual life, understood in a Christian way, is defined as welcoming the vital Spirit, and it is realized by confronting the biblical text because the text has a particular bond with the Spirit that inspired it, and as such, it is inspired. ${ }^{5}$

The link between the theme of the spirit and that of Scripture's inspiration has a particular relevance as a specific characteristic of Chrétien's phenomenology that corresponds to the consideration of the word (according to the call/response device) and, in particular, the role it assumes in philosophical, literary, and religious writings. The word realizes and actualizes what has been proposed earlier (regarding the connected nature of subjectivity) by affirming that every response is always the result of a plurality of prior voices. A word is, indeed, never strictly singular, but in its singularity, it expresses a deeper plurality. At this point of his reflection, the general structure of call and response is applied to the Bible, mediated by the Spirit and its relationship with the reader. ${ }^{6}$

According to Chrétien, understanding what is written in the Holy Scripture is only possible if the reader does not approach the Bible using exegetical techniques and literary analysis and instead relies on spiritual interpretation. Once again, it is precisely through the image of the wind/breath, taken from the story of Elijah's encounter with God (1 Kings 19), that Chrétien defines what the correct relationship between the reader and the biblical text consists of: "listen to the weak breath of murmuring through the fury of the hurricane, and listen to the violent breath of the storm through the touch of the breeze, because it is the same Breath, and the same God, who are addressed to us through these different manifestations" (Chrétien 2009a, p. 23). Tackling the theme of inspiration in order to define 
the spirit, Chrétien provides another image that joins that of the wind and breath-that of fire. Once again, we deal with a vital dynamic of transformation: "the biblical fire is not, but it burns, that is, it happens" (Chrétien 2003, p. 77).

The spiritual act of biblical reading is possible because there is a consonance of nature between the spirit of the reader and the Spirit that characterizes the biblical words: "only fire makes fire intelligible, only fire explains itself and it gives to enter into him without being blinded or destroyed; only the fire of the Holy Spirit makes us understand the fire of Scripture" (Chrétien 2003, p. 139). The inspiration of the Bible makes it a living text that will never be considered a dead letter. ${ }^{7}$ The consequences of this are crucial for the status of the subjects who read those words. Those who read the Bible are involved in the act of reading: they are engaged in its actuality, that is, they are encouraged to make their reading a vital act, able to operate over time, so that the call that the text of the Bible contains is still relevant in the present day.

For this reason, the historical-critical methodological approach is drastically rejected: according to Chrétien, it reduces the Biblical writing by fragmenting it, suppressing its vital charge, and transforming it into a mere object of study. On the contrary, spiritual reading overturns the hermeneutical primacy: it ensures the priority of the text over the reader and allows the transfer of the vital charge to the latter. The reader must, therefore, "let himself be read" by Sacred texts: this receptive act allows the reader to be reached by that same spirit, and so allows their own spirit to be revitalized by the biblical spirit. ${ }^{8}$

Following this theme of inspiration, we can clearly state the significance for the reader-and consequently for the human being as such — of being rooted in its spiritual connection: the reader can be read by the Bible because they are both inhabited by God's Spirit, which resonates in the text and in the reader too. The biblical text can therefore be considered the necessary medium that permits the spirit to emerge with its vital charge in everyday life: every reader can fully read the Bible only if they consent to its call, and this is realized when they manifest in their life the response to it. This response can be understood as a spiritual act because it consists in a total engagement in life that implies that the personal and inner dimension is realizable only in its exterior and public form.

\section{The Communitarian Response to the Spirit}

This article has been trying to argue for a form of the human spirit that is neither reduced to interiority nor extraneous from the fleshly dimension. In the last section, we focused on the Christian tradition in which the Holy Spirit gives life to the human spirit through the biblical text. We will now examine why focusing on reading the biblical text as a spiritual act fully realizes what was initially said at an anthropological level, and so will clarify why and how reading the Bible this way defines human spirituality as embodied and communal.

By rejecting the contemporary hermeneutic device that would attribute a constituting role to the reader, Chrétien opens on to the equally divisive question of the status of the subject. The fact that the reader is interpreted by the text they read, or that they allow their life to be called by the Word of God, would allow them to assimilate the same spiritual force that makes that word a living word. Indeed, what is contained in the Bible challenges the reader's existence in their own history and allows them to define the decisions they wish to make in relation to their life. More accurately, it creates the possibility of an encounter that does not only involve individual faculties, such as the interpretive or the reflective, but life in its entirety: "spiritual reading requires our existence as a guarantee-it is a personal encounter with God through his humanly transmitted word" (Chrétien 2003, p. 72). The act of reading, and the act of reading the Bible in particular, is not only one of the many acts that compose human life, but it summarizes the dimension of life as such because it establishes the relationship with God in a personal and total way.

This total relation to God is founded in the nature of the word, which is understood by Chrétien as a radical call that implies the subject's response. ${ }^{9}$ The reader finds themselves needing to take a position based on what they have read. This taking-a-position is the 
absolute form of the subject's defining itself, captured phenomenologically in the notion of the voice. However, for Chrétien, this self-definition can never be extraneous to what is heard. Rather, the strength of the voice-which is concretized in the word and finds its highest form in the biblical words-consists precisely in the responsive and inter-connected character of one's personal existence. ${ }^{10}$ This can be understood as a real conversion: whenever someone takes their position according to the call that they recognize as addressed to them, they undergo a radical change of their own life, because of the excessive quality of the call in relation to the finitude of their response. Hence, their taking a position consists in a never-ending work that involves their whole life. ${ }^{11}$

The response aroused by the self-exposure of the Bible's reader corresponds to a radical change in the reader's own voice, that is, to the possibility of hosting the word that animates the Bible in the reader's own words, starting from its listening: "to listen is to be opened to the other and transformed by the other at our most intimate core. Intimacy, in these ways of thinking, is neither escape or shelter, but rather the place of broader exposure" (Chrétien 2004b, p. 63). ${ }^{12}$ This event is made possible by answering the call that is recognized as requiring its own response; the communication of the spirit that gives shape to the Bible comes from this event, and through it the reader receives its vitality. In this case, any solipsistic reduction is overcome, because the word pronounced by the individual is already plural, since-in its finitude - it hosts the biblical word from which it was transformed. This original otherness has repercussions for the communal form that characterizes the acceptance of the call of the Bible: a single answer is not enough, so an adequate answer can only be that which is constructed in the plural form: "there is indeed no contradiction between the always communitarian character of the reading and interpretation on the one hand and its singular and singularizing character on the other, in which the Bible becomes a kind of principle of spiritual individuation (in other words, that which announces to me and permits me to discern my vocation)" (Chrétien 2015, p. 17). ${ }^{13}$ Throughout Chrétien's writing, but in particular in the pages he devotes to the text and to the Holy Scripture, it is clear that the dichotomous relationship (e.g., self-other, subjectworld) is a reductive form of the bond to alterity. Indeed, the authentic link is communal, because it is the only one which can maintain the plural form inscribed in the polyphony of speech. Consequently, real individuation is spiritual: it is only the vital constitution of the spirit, intersubjective and relational, that can establish the dynamic form of the subject, realized in hospitality as a further form of opening to alterity.

The spiritual reading of the Bible cannot be understood as a binary relationship between the text and the reader; rather, it is authentic when it is polyphonic, that is, when it involves the entire community of readers and is delivered in turn to the totality of subjects. The communal dimension takes its roots in the structure of speech: even in a dialogue, it is never a question of a mere binary relationship, because every word is the host of other voices that are invoked and implied in the dialogue. ${ }^{14}$ If reading the Bible was conducted in isolation, it would contradict the vital dimension that characterizes that text; in reality, an authentic spiritual reading involves the full exposure of the subject to divine transcendence (coram Deo-in the presence of God), which is only possible, as we will now see, in the experience of prayer, or, more precisely, of liturgical prayer (coram populo-in public) (see Chrétien 2002a, p. 85).

\section{Prayer as the Embodied Spiritual Act}

The possibility of living according to a spiritual dimension encapsulates the relationship with the Bible, the inspired text. The spiritual reading of the Bible is considered by Chrétien to be the only authentic one, as this modality preserves the vitality of the spirit. Additionally, such a reading is one of the most complete human acts, as it determines the subject, beginning with their freedom and transforming them deeply, letting their spiritual dimension emerge: "letting ourselves be transformed by the inspired word presupposes constant acts on our part. Prayer, prayer for enlightenment and for the ability to see, is the first and last among them. It is necessary for the intelligence to make itself a prayer in 
order for it to become an exegete, that is to say, to read as it allows itself to be read [...] in spirit and in truth [...] the words that come from the Spirit" (Chrétien 2015, p. 11).

This reading is the spiritual act par excellence, and it corresponds to prayer. ${ }^{15}$ Following Chrétien's analysis of this phenomenon allows us to understand what form of subjectivity derives from it. The prayer that corresponds to the reading of the Bible is an act of listening and not an act of simply pronouncing words, and the response to the call of the text is configured as listening achieved through reading. In particular, Chrétien refers to the monastic technique of lectio divina (prayerful reading) (see Chrétien 2004a, p. 18), and his analysis shows that the spiritual response to the words of the sacred text is always corporeal and communal.

Chrétien considers prayer as an act of speech: it is a particular phenomenon that achieves the radical exposure of the subject who prays towards the divinity to which they are addressing. In prayer, a reversal of the common correlative structure between subject and object, speaker and listener, is achieved. In prayer, "the words of our speech affect and modify the addresser, and not the addressee. We affect ourselves as we stand before the other, in a movement towards him" (Chrétien 2004a, p. 21). The one who speaks by praying actually listens: turning to God, they let the divine call reach their life, and by responding, they shed light on the call that is addressed to them. Each type of vocal prayer and, in particular, lectio divina (Chrétien refers, above all, to the fact that lectio divina was practiced in medieval monasteries, where reading was almost always aloud and not in mental form) is defined by two constitutive aspects: it is a spiritual act that takes place corporally ${ }^{16}$ and publicly (see Chrétien 2004a, p. 33).

The Christian tradition realizes these aspects with a particular form of prayer that follows from the relationship to the Bible, that is, prayer through the psalms. Not only-as we have just suggested-is the human being involved in a spiritual dimension by its relationship with the biblical text, but this link is necessarily accomplished in a communal and public way. Liturgical prayer is a response to the call addressed by the Bible given through the Bible itself. To use the words of the psalms corresponds to the first way to give voice to the spirit that inhabits those words. It is, in fact, a very particular form of response to the biblical word, as it is achieved by giving its own voice to words that are, in turn, biblical. This type of prayer, in its supreme form, contributes to realizing the spiritual configuration of the subject: "to pray the psalms is not to add one theoretical interpretation to another, it is to allow oneself to be interpreted by them, to offer one's own life, to which they give a much deeper expression in the words of God, as a space in which they can echo and their promise be heard" (Chrétien 2004a, p. 36).

This prayer usually takes place through two choirs of people: one takes the floor when the other is silent, practically creating an intertwining of call and response named antiphonary. The antiphonary completes the communal polyphony that characterizes the Word, showing how the singularity of the subject is only realized within the community. Each one has the responsibility of letting the word of God resonate through their own voice, thus handing it over to others to respond to it in turn. In the prayer of the psalms, this becomes visible and audible: it is possible to hear the call of the word thanks to the other, but it immediately brings into play the subject, who must respond in a personal way (see Chrétien 1989, p. 42).

The persistence of the vocal dimension of speech, combined with the attention paid to the communal realization of prayer in the liturgical assembly, insists on the fleshly expression of the spirit. Chrétien makes clear that is not possible to understand the spirit beyond the concrete and finite form ensured by bodies, and he also clarifies that interiority is not reducible to a solipsistic or disincarnated dimension. Assuming the Christian tradition as its fundamental source, Chrétien develops a spiritual conception according to this particular point of view. However, this does not mean that his theory is only available to or for a special perspective of faith: first of all, he derives a theoretical analysis with an universal value; furthermore, the inclusion of this proposal in the thematic area of speech 
and of the act of reading allows his theory to also be extended to other religions that give a definitive relevance to a sacred text. ${ }^{17}$

\section{Conclusions}

This analysis of Chrétien's proposal has shown that it is not possible to directly thematize the difference between the religious dimension and the spiritual dimension. Chrétien does not do so because the theoretical aspects of his proposal reject any dichotomous form. In fact, starting from the description of the peculiar aspects of the spiritual dimension, he shows how constitutive the intersubjective form is, in which the dialogic features are determined in a communal dimension without any loss of the individual peculiarities of the subject.

Chrétien's work is not a simple description of religious experience, but is also a philosophical-more specifically, a phenomenological-interpretation. For this reason, his theory is particularly interesting, since it is centered on the particular aspects of speech. Speaking is a common experience for every human being and cannot be reduced to the act of transmitting information. On the contrary, we can summarize-agreeing with the words of a keen scholar of Chrétien's proposal-that speech itself is a spiritual act, because it "is the very incarnation of spiritual life, at least if the word "spirit" may indicate an attunement to what comes into this life without being contained here" (Bloechl 2002, p. xv). Allowing the establishment of a bond between human beings, speech introduces to the spiritual dimension what is common to humankind, because in the act of speech, the excess characterizing reality, as such, is revealed. One of the more common and, at the same time peculiar, human acts can be defined as spiritual. In fact, it is never possible to reduce the fact of speaking to a mere communicative apparatus, because speech reveals a transcendence implied in the polyphony that has generated the singular voice. This radical link is permitted because speech manifests itself as already determined by a vital dynamic, as the personal response begins with the excessive call that the speech encloses.

For this reason, the biblical word-in which the call/response device is defined as originating from the divine spirit that inhabits it - is a radicalization of that common structure, and it leads to the irrevocable definition of spiritual experience as embodied and intersubjective.

Chrétien's theory gains an incarnate and communal dimension of the spirit only by insisting on the dramatic structure of speech. In fact, Chrétien often insists on the priority of the call and on the necessity for the subject to be read by the Bible he reads, so that it remains undecided if the singular response is really free and creative, or if in some way it remains implied by the call. If the dichotomy between interiority and exteriority and between personal and public dimension is overcome, a more detailed consideration of all the possibilities of the subject could enrich the variety of the communal response. In fact, the communal link is much more than a sum of singular responses to the call: it is determined by the mutual response of each member to another. It suggests that the sharing of each one's own individuation-defined by Chrétien as the spiritual dimension of speech-can develop an historical involvement that also implies the different ways of its developing, which is embedded in the dramatic and unpredictable form of the response.

Chrétien's proposal decisively overcomes the alternative scheme of a solipsistic subjectivity that is defined by a firm distinction between its inner spiritual life and its public and intersubjective acts. The focus he puts on the liturgical dimension, on the act of reading and in general on the communal dimension of speech, not only shows the public and carnal dimension of spirit, but also, and above all, underlines that the authentic religious dimension is not divisible from its inner core (which would correspond to a personal spiritual dimension), because religion in its historical and public form is nothing but the manifestation of vital spirit. This approach recognizes how much the personal form is given in a continuous dialogue, thus determining an endless quest for ever-wider hospitality, since this does not reside in an ethical imposition, but in the free response to the spirit's calls. 
Funding: This research received no external funding.

Conflicts of Interest: The author declares no conflict of interest.

\section{Notes}

1 This can be considered one of the consequences of the modern age and of Enlightment thought that promoted a progressive shifting of the faith dimension to the private sphere, as described in Angelini (2014, pp. 123-26).

2 It is possible to understand this posture as beginning from theological interpretations that reduce the relationship between faith and religion proposed in Barth (1933), chap 7 to a dichotomy, or that emphasize the Religionless Christianity proposed in Bonhoeffer (1997, pp. 278-82). Contemporary sociology of religion has underlined the progressive personalisation of spiritual life despite the institutional dimension of religion that carachterizes the secular age (see Heelas and Woodhead 2004). Finally, it is good to remember the postmodern philosophical way to decipher religion contained in Vattimo (2002) and Vattimo (2007).

3 As will be explained in this article, this structure is not only related to a simple stylistic choice, but the philosophical style of Chrétien's phenomenology is motivated by a fundamental theory, implying a significative relationship between authors of different period and fields of knowldege. In particular, Chrétien gives relevant attention to late antiquity and neoplatonism (especially Philon of Alexandria and the Fathers of the Church); to the spiritual and monastic tradition of the Middle Age (see Chrétien 2005); and to the modern novel (see Chrétien 2009b; Chrétien 2011). Chrétien's dialogue with this huge crowd of authors has a philosophical aim rooted in the phenomenological tradition; in particular, the author develops a much more Heideggerian posture (especially starting from Heidegger 1971) than a Husserlian one, and he declares expressly his debt to the analysis of Henry Maldiney (see Chrétien 2002b, p. 129 and Gramont 2017, pp. 9-25). In general, Chrétien's phenomenology can be understood as one of the creative developments of French phenomenology, with evident links to Jean-Luc Marion's phenomenology, although his own path permits a much more significant place for the first person role (see Peruzzotti 2015, pp. 65-73).

4 Chrétien develops his proposal by an enquiry into the polysemic dimension of the word "spirit", rooted in its biblical meaning in Hebraic, Greek and Latin translations. The biblical word ruah designates God's spirit, as a vital (referring to breath) and creative force (see Ezekiel, chap. 37). This word is also employed to describe the spirit as the wind, for example in Genesis 1:2. In the Greek (pneuma) and the Latin (spirit) translations the word maintains the three meanings of breath, spirit and wind (as it is clear in John 3: 1-21); by consequence the spiritual dimension and the Holy Spirit are described by the act of breathing and by the image of the wind. According to Chrétien this equivalence is not accidental nor simply semantic, but reveals the deeper structure of the human spiritual dimension as founded in the material.

5 According to the idea of divine inspiration, the Bible's author is not only the one that wrote the text but also God that inspired him. This means that biblical speech is, since its origin, determined by a call and response link and that its words are just the hospitable dimension of the God-human dialogue. For a classical approach to the inspiration problem, see (Rahner 1961). Chrétien understands this connotation of the Sacred Scripture, stating that "to consider the Bible inspired is to believe that it is the Word of God, the true word of the true God, conferred and delivered by the spirit, the mouth, and the hand of ever-new humans" (Chrétien 2015, p. 6).

6 Call/response is the structure through which Chrétien develops the phenomenological correlation. He emphasises the primacy of the call in its excessive and absolute dimension over the human response; however, the second is necessary and determinant in its free finitude because only the response can show the priority of the call. It is due to this structure that scholars are divided concerning Chrétien's belonging to the phenomenological movement: Janicaud's well known critique (see Janicaud 2000, pp. 68 ss.) emphasizes an undue theological debt, while on the opposite side, the role of the call's excess as the foundation of correlation is considered a necessary revision of the phenomenological structure so as to avoid every type of idealism; see (Canullo 2004, pp. 275-83; Thirion 2002, pp. 57-63; Gondek and Tengelyi 2011, pp. 569-80).

7 "That the human and divine Scripture is inspired signifies the coexistence in it of the living and the dead, the present and the past, the one and the multiple" (Chrétien 2015, p. 8).

8 It is indeed useful to consider the critical remarks proposed in Gisel (2005): the Swiss theologian avoids his misgiving that Chrétien's proposal completely deletes the subjective's role. In fact, the opportunity to be read should open to a second step in which the reader, who has received from the text its vital dimension, applies it to a new and creative involvement in its personal history.

9 "Any radical thought of the call implies that the call is heard only in the response" (Chrétien 2004b, p. 30).

10 "Not only must there be a reciprocity between speaking and hearing, but our voice, in order to be a voice, must always already be open, at its most intimate core, to the speech of others, which calls it to be its shelter. The voice always already translates" (Chrétien 2004b, p. 45).

11 Allowing the Bible to interpret the reader's existence is therefore equivalent to speaking in turn, if we consider that taking the floor does not mean simply emitting sounds, but acting: "that the word is of fire, both burned and burning, means that it is an acting word, which is ours insofar as we have been, and still remain, exposed to its action, an action of which we are not the source. That the word is of fire refers [...] to the alteration of our voice through a word that is not just ours" (Chrétien 2003, p. 50). 
It is indeed sometimes a bit difficult to establish the real weight of human freedom in the balance between call and response proposed by Chrétien: the radical change of the reader determined by their exposition to the Bible should involve a creative and personal determination of their freedom, but Chrétien prefers to dwell on the first part of the dynamics, concerning the role of the biblical word, and not on the dynamics of human action (except for prayer), but the vital and fiery dimension inhabiting the word and transmitted by the spirit could be highlighted more strongly.

13 This aspect is founded on the structure of speech as such which is excessive and involving totality: "every initiative on my part only perpetuates an immemorial yes, in the rift between two forms of excess. Infinite excess, first of all, of the call over the answer, since the call is of the infinite: by calling me as a person, it calls me not as an isolated and abstract being but calls the totality of the world in space and time along with me, in the inexhaustible chorus of which I am only one voice enduring a perpetual inchoation" (Chrétien 2004b, p. 19).

14 "The act of speech cannot be thought on the basis of the simple duality of you and me. As soon as you speak to me, we are already all there, even the dead, and those who will one day come also. The interlocutors [...] are thus never only two people: even a face-to-face conversation is heavy with a distant rumour, and even intimacy has its own wide-open spaces" (Chrétien 2004a, p. 10).

In Chrétien's phenomenology, prayer is the radicalization of word and it is therefore word's paradigm, see (Greisch 2002, p. 255). "To pray vocally is to make the body an essential element of prayer" (Chrétien 2004a, p. 32).

Concerning the possible links between the act of reading the Bible and the spiritual act realized by confronting the Qur'an, see (Peruzzotti 2018, pp. 357-60).

\section{References}

Angelini, Giuseppe. 2014. La Fede. Una Forma per la Vita. Milano: Glossa.

Barth, Karl. 1933. The Epistle to the Romans. Translated by Edwyn M. Hoskyns. London: Oxford University Press.

Bloechl, Jeffrey. 2002. Translator's Introduction. In The Unforgettable and the Unhoped for. Edited by Jean-Louis Chrétien Bloech. Translated by Jeffrey Bloech. New York: Fordham University Press, pp. vii-xv.

Bonhoeffer, Dietrich. 1997. Letters and Papers from Prison. New York: Touchstone.

Canullo, Carla. 2004. La fenomenologia Rovesciata. Percorsi Tentati in Jean-Luc Marion, Michel Henry e Jean-Louis Chrétien. Torino: Rosenberg \& Sellier.

Chrétien, Jean-Louis. 1989. L'antiphonaire de la Nuit. Paris: L'Herne.

Chrétien, Jean-Louis. 2002a. Saint Augustin et les Actes de Parole. Paris: PUF.

Chrétien, Jean-Louis. 2002b. The Unforgettable and the Unhoped for. Translated by Jeffrey Bloechl. New York: Fordham University Press. Chrétien, Jean-Louis. 2003. L'intelligence du Feu. Réponses Humaines à une Parole de Jésus. Paris: Bayard.

Chrétien, Jean-Louis. 2004a. The Ark of Speech. Translated by Andrew Brown. London and New York: Routledge.

Chrétien, Jean-Louis. 2004b. The Call and the Response. Translated by Anne Davenport. New York: Fordham University Press.

Chrétien, Jean-Louis. 2005. Symbolique du Corps. La Tradition Chrétienne du Cantique des Cantiques. Paris: PUF.

Chrétien, Jean-Louis. 2009a. Pour Reprendre et Perdre Haleine. Dix Brèves Méditations. Paris: Bayard.

Chrétien, Jean-Louis. 2009b. Conscience et Roman, vol I, La conscience au grand jour. Paris: Minuit.

Chrétien, Jean-Louis. 2011. Conscience et Roman, vol II, La conscience à mi-voix. Paris: Minuit.

Chrétien, Jean-Louis. 2015. Under the Gaze of the Bible. Translated by John Marson Dunaway. New York: Fordham University Press.

Gisel, Pierre. 2005. Lire théologiquement et spirituellement les écritures. Recherches de Science Religieuse 93: 533-43. [CrossRef]

Gondek, Hans-Dieter, and László Tengelyi. 2011. Neue Phänomenologie in Frankreich. Berlin: Suhrkamp.

Gramont, Jérôme de. 2017. L'aventure de la parole selon Jean-Louis Chrétien. Comprendre 19: 9-30.

Greisch, Jean. 2002. Le Buisson Ardent et les Lumières de la Raison. L'invention de la Philosophie de la Religion, vol. II, Les Approches Phénoménologiques et Analytiques. Paris: PUF.

Heelas, Paul, and Linda Woodhead. 2004. The Spiritual Revolution. Why Religion is Giving Way to Spirituality. Oxford: Blackwell. Heidegger, Martin. 1971. On the Way to Language. Translated by Peter D. Hertz, and Joan Strambaugh. New York: Harper \& Row. Janicaud, Dominique. 2000. "The theological Turn of French Phenomenology." Phenomenology and the "Theological Turn": The French Debate. Translated by B. G. Prusak. New York: Fordham University Press.

Peruzzotti, Francesca. 2015. Lo Scritto e il suo Lettore. In Ascolto di Jean-Louis Chrétien, Martin Heidegger, Jean-Luc Marion. Milano: Mimesis.

Peruzzotti, Francesca. 2018. La lettura ospitale. Tracce di fraternità a partire da una lettura cristiana del Corano. Archivio Teologico Torinese 24: 349-63.

Rahner, Karl. 1961. Inspiration in the Bible. Translated by Charles H. Henkey. New York: Herder \& Herder.

Thirion, Benoit. 2002. L'appel Dans la Phénoménologie de J.-L. Chrétien, Contexte et Introduction. Paris: L'Harmattan.

Vattimo, Gianni. 2002. After Christianity. Translated by Luca D’Isanto. New York: Columbia University Press.

Vattimo, Gianni. 2007. Toward a Nonreligious Christianity. In After the Death of God. Edited by Jeffrey W. Robbins. New York: Columbia University Press, pp. 27-46. 